\title{
ProteCting AMERICA'S PASTIME: The NeCESSITY OF MAJOR LEAGUE BASEBALL'S ANTITRUST EXEMPTION FOR THE SURVIVAL OF MINOR LEAGUE BASEBALL
}

\author{
BRADLEY V. MURPHY*
}

\section{INTRODUCTION}

"How can you not be romantic about baseball?"1 Imagine a warm summer evening in Rome, Georgia. This city of just under 36,000 residents $^{2}$ is home to the Rome Braves, the Class-A affiliate of the Atlanta Braves. ${ }^{3}$ State Mutual Stadium is filled to capacity as the local residents pack the stands to cheer on their hometown Braves. ${ }^{4}$ The smell of peanuts, popcorn, and hotdogs emanates throughout the stadium. A beer vendor climbs up and down the stadium steps hollering, "Ice cold beer!" Between innings, children are brought out on the field to partake in on-field promotions. After the game, these same children line up to run the bases, meet the mascot, and enjoy the postgame firework display. This minor league game brings the people of Rome, Georgia together and provides them with a common identity.

Bradley Reynolds, general manager of the Double-A Mobile BayBears, highlighted the importance of minor league baseball when he said, "What keeps fans coming back isn't baseball. If they want a better baseball game, they can see it on ESPN. This is about affordability, family fun, wholesome entertainment. That's what makes this business unique and what makes it work." Considered to be "America's National Pastime," baseball holds a special place in the hearts of many. In "Field of Dreams," arguably the most famous baseball movie of alltime, Terence Mann, an author played by James Earl Jones, discussed the importance of baseball to many Americans:

* J.D. Candidate, 2016, Indiana University Robert H. McKinney School of Law; B.S. 2013, Manchester University, North Manchester, Indiana. I would like to thank Professor Max Huffman for his invaluable feedback throughout the Note-writing process, Professor Gary Roberts for his guidance in selecting this topic, and my family and friends for their unconditional support.

1. Moneyball (Columbia Pictures 2011).

2. State \& County QuickFacts: Rome, Georgia, U.S. Census BurEAu (July 8, 2014, 6:43 PM), http://quickfacts.census.gov/qfd/states/13/1366668.html [http://perma.cc/TW23-QVLE].

3. The Official Site of the Rome Braves, Rome BRAVES, http://www.milb.com/content/ page.jsp?ymd $=20081219 \&$ content_id $=41164908 \&$ fext $=. j s p \& v k e y=n e w s \_t 432 \&$ sid $=t 432$ [http://perma.cc/9ZCY-TEKX] (last visited Jan. 16, 2016).

4. Id.

5. Bruce Schoenfeld, Minor League Teams, But Mighty Big Numbers As Franchise Values Soar, SPORTs Bus. J. (Aug. 4, 2014), http://www.sportsbusinessdaily.com/Journal/Issues/2014/08/ 04/Franchises/Minor-league-teams.aspx [http://perma.cc/A6FS-RPYJ].

6. See John Thorn, The 'Secret History' of Baseball's Earliest Days, NPR (Mar. 16, 2011, 11:07 AM), http://www.npr.org/2011/03/16/134570236/the-secret-history-of-baseballs-earliest-days [http://perma.cc/PD69-HVTZ] (discussing the rise of baseball in America and the consideration of the sport as "America's Pastime").

http://dx.doi.org/10.18060/4806.0107 
They'll come to Iowa for reasons they can't even fathom . . It's only $\$ 20$ per person. They'll pass over the money without even thinking about it: for it is money they have and peace they lack. And they'll walk out to the bleachers; sit in shirtsleeves on a perfect afternoon. They'll find they have reserved seats somewhere along one of the baselines, where they sat when they were children and cheered their heroes. And they'll watch the game and it'll be as if they dipped themselves in magic waters. The memories will be so thick they'll have to brush them away from their faces ... The one constant through all the years ... has been baseball. America has rolled by like an army of steamrollers. It has been erased like a blackboard, rebuilt and erased again. But baseball has marked the time. This field, this game: it's a part of our past ... It reminds us of all that once was good and it could be again. ${ }^{7}$

This colloquy exemplifies people's emotional connection to the game of baseball. Although some argue baseball is slipping in terms of popularity, ${ }^{8}$ Americans' continued passion for baseball cannot be measured simply by looking at metrics such as television ratings - an admittedly unscientific process. ${ }^{9}$ Instead, baseball's relevance must be looked at for what it has provided to millions of people for well over a century_- "local fan-base fervor and enduring cultural relevance." 10

Baseball is different from any other sport, both on and off the field. Nothing better exemplifies this on-field difference than when Ted Williams, one of the greatest hitters ever to play the game, said, "Baseball is the only field of endeavor where a man can succeed three times out of ten and be considered a good performer." 11 The off-field difference between baseball and other sports is a bit more drastic. Baseball is the only professional sports league immune from U.S. antitrust laws, and this immunity extends to the minor leagues. ${ }^{12}$

With the passage of the Sherman $\mathrm{Act}^{13}$ in 1890 and the Clayton Antitrust

7. FIELD OF Dreams (Universal Pictures 1989).

8. See Jonathan Mahler, Is the Game Over?, N.Y. Times (Sept. 28, 2013), http://www. nytimes.com/2013/09/29/opinion/sunday/is-the-game-over.html?pagewanted=all\&_r=0 [http://perma.cc/S42A-Y25Y] (noting there is "no sense comparing baseball's [national television ratings] numbers to football's, which exist in a whole other Nielsen's stratosphere" and "[i]n 2012, the N.B.A.'s regular season ratings . . . were nearly double those of Major League Baseball").

9. See Allen Barra, Sorry NFL: Baseball Is Still America's Pastime, Atlantic (Oct. 30, 2013, 9:53 AM), http://www.theatlantic.com/entertainment/archive/2013/10/sorry-nfl-baseball-isstill-americas-pastime/280985/ [http://perma.cc/ZFK2-6VYM] (arguing "metric[s] ignore[] other strong indicators" of Major League Baseball's popularity).

10. Id.

11. Ted Williams' Quotes, BASEBALl Almanac, http://www.baseball-almanac.com/quotes/ quowilt.shtml [http://perma.cc/BYE6-TPCY] (last visited Jan. 13, 2015) (quoting THE 2006 ESPN Baseball Encyclopedia 5 (Pete Palmer et al. eds., 2006)).

12. See infra Part III (discussing the creation and prolonged existence of Major League Baseball's antitrust exemption).

13. 15 U.S.C. $\S 1$ (2012). 
$\mathrm{Act}^{14}$ in 1914 , Congress attempted to promote fair competition throughout the marketplace. ${ }^{15}$ Section 1 of the Sherman Act makes "[e]very contract, combination in the form of trust or otherwise, or conspiracy, in restraint of trade or commerce among the several States ... illegal." ${ }^{\text {"16 }}$ Further, Section 2 of the Sherman Act states: "Every person who shall monopolize, or attempt to monopolize, or combine or conspire with any other person or persons, to monopolize any part of the trade or commerce among the several States ... shall be deemed guilty of a felony." 17 The Clayton Act provides standing requirements for individuals claiming antitrust violations. ${ }^{18}$

Even with the passage of the Sherman and Clayton Acts, the Supreme Court has continued to rule that Major League Baseball ("MLB") is exempt from antitrust laws. ${ }^{19}$ In what is known as the "Baseball Trilogy," ${ }^{20}$ the Supreme Court refused to apply the requirements of the antitrust laws to MLB ${ }^{21}$ The antitrust exemption extends to MLB franchise relocation and appears to have been recently reaffirmed when the Supreme Court denied certiorari to San Jose's challenge. ${ }^{22}$ The district court had dismissed San Jose's challenge on the basis of baseball's historic exemption ${ }^{23}$ and San Jose appealed the decision to the Ninth Circuit, which heard oral arguments on August 12, 2014 and rendered a decision on January $15,2015 .^{24}$ On February 3, 2015, the San Jose City Council voted to petition the Supreme Court for certiorari in hopes that the Court would finally strike down baseball's exemption. ${ }^{25}$ Although the Supreme Court denied certiorari to the City of San Jose, given the Court's recent willingness to overrule outdated antitrust precedent, ${ }^{26}$ baseball's antitrust exemption could be in jeopardy

14. Id. $\S 12$.

15. Id. $\S 1$.

16. Id.

17. Id. $\S 2$.

18. Id. $\S 15$.

19. See infra Part III (discussing the creation and prolonged existence of Major League Baseball's antitrust exemption).

20. See Flood v. Kuhn, 407 U.S. 258 (1972); Toolson v. N.Y. Yankees, Inc., 346 U.S. 356 (1953); Fed. Baseball Club of Balt., Inc. v. Nat'1 League of Prof'1 Baseball Clubs, 259 U.S. 200 (1922).

21. See Flood, 407 U.S. 258; Toolson, 346 U.S. 356; Fed. Baseball Club of Balt., Inc., 259 U.S. 200.

22. See infra Part III.D (discussing the antitrust challenge to baseball's relocation requirements brought by San Jose).

23. City of San Jose v. Office of the Comm'r of Baseball, No. C-13-02787, 2013 WL 5609346, at*16 (N.D. Cal. Oct. 11, 2013), aff'd, 776 F.3d 686 (9th Cir. 2015), cert. denied, 136 S. Ct. 36 (2015).

24. See infra Part III.D (discussing the Ninth Circuit's decision in San Jose).

25. Mike Rosenberg, San Jose vs. MLB: Lawsuit over A's Appealed to U.S. Supreme Court, SAN JoSe MERCURY News (Feb. 3, 2015, 1:53 PM), http://www.mercurynews.com/bay-areanews/ci_27450804/san-jose-appeals-lawsuit-against-mlb-u-s [http://perma.cc/AN8L-RENB].

26. See Leegin Creative Leather Prods. v. PSKS, Inc., 551 U.S. 887 (2007) (overruling Dr. 
in the near future, potentially spelling trouble for the minor leagues.

The purpose of this Note is to discuss the importance of Major League Baseball's antitrust exemption for the continued existence and success of Minor League Baseball. In particular, this Note explains the impact of restricting Minor League Baseball teams from relocating and paying their players above a prescribed minimum, and looks at potential challenges to the exemption that could affect Minor League Baseball. Part I discusses the unique structure of both Major League Baseball and Minor League Baseball, including franchise relocation and pay structure. Part II focuses on antitrust laws in the United States, notably the Sherman and Clayton Acts, the goals of antitrust law, and the different methods of analyzing antitrust cases. Part III explores the origin of the Supreme Court's antitrust exemption for Major League Baseball and cases that have furthered the exemption. Finally, Part IV argues the importance of Major League Baseball's antitrust exemption for the survival of Minor League Baseball. Specifically, given the Supreme Court's decisions in antitrust cases, professional baseball's location requirements and pay structure would likely be found to violate antitrust laws. As a result, drastic changes would occur within the landscape of Minor League Baseball if the antitrust exemption is repealed, depriving small-market cities from enjoying minor league baseball and overall decreasing consumer welfare.

\section{Structure of Professional Baseball}

\section{A. Major League Baseball}

The structure and operation of MLB is governed by the Major League Constitution (hereinafter "League Constitution"). ${ }^{27}$ The League Constitution establishes, "[t]here shall be [thirty] Major League Clubs . . . The Clubs shall be organized into two Leagues, the American League and the National League, with three divisions in each league. ${ }^{28}$ These divisions are the East Division, Central Division, and West Division. ${ }^{29}$ Furthermore, the League Constitution designates an "operating territory" in which each Club "ha[s] the right and obligation to play baseball games as the home Club."

Miles Medical Co. v. John D. Park \& Sons Co., 220 U.S. 373 (1911)—antitrust precedent that had stood for nearly one hundred years); see also State Oil Co. v. Khan, 522 U.S. 3 (1997) (overruling Albrecht v. Herald Co., 380 U.S. 145 (1968) - antitrust precedent that had stood for nearly thirty years).

27. See generally Major League Baseball Clubs, Major League Constitution (2005), available at http://www.ipmall.info/hosted_resources/SportsEntLaw_Institute/League $\% 20$ Constitutions\%20\&\%20Bylaws/MLConsititutionJune2005Update.pdf [https://perma.cc/R2QJDF32].

28. Id. at 10-11 (art. VIII, section 1).

29. Id.

30. Id. at 13-17 (art. VIII, section 8). 


\section{B. Minor League Baseball}

The current structure of Minor League Baseball was first established in 1963. ${ }^{31}$ Minor league teams are grouped into different "classes." 32 There are three main classes: Triple-A, Double-A, and Single-A. ${ }^{33}$ Single-A is further divided into High-A, Low-A, A-Short Season, and Rookie. ${ }^{34}$ Within each class are different leagues. For example, Triple-A is made up of the International League, the Pacific Coast League, and the Mexican League. ${ }^{35}$ In all, there are 160 minor league franchises affiliated with major league clubs. ${ }^{36}$

The different classes represent the varying competition levels that players will face. ${ }^{37}$ In theory, as a player moves up classes (e.g., moving from Single-A to Double-A), the player will face better competition. ${ }^{38}$ Therefore, Single-A typically encompasses younger players who were recently drafted. In contrast, Double-A and Triple-A franchises often field teams with older, more experienced players who are more likely to be called up by a MLB club. ${ }^{39}$

\section{Franchise Relocation in Professional Baseball}

1. Major League Baseball Relocation.-Relocation of MLB franchises was not always as uncommon as it is today. ${ }^{40}$ In fact, in a twenty-year span from 1953 through 1972, ten MLB franchises relocated to a different city. ${ }^{41}$ However, since 1972, only one franchise has relocated, ${ }^{42}$ with that relocation taking place in 2005 when the Montreal Expos relocated to Washington, D.C. ${ }^{43}$

31. See John Cronin, Truth in the Minor League Class Structure: The Case for the Reclassification of the Minors, 42 BASEBALL RES. J. 1 (2013), available at http://sabr.org/ research/truth-minor-league-class-structure-case-reclassification-minors [https://perma.cc/HYP8UPES] (discussing the history and current structure of Minor League Baseball).

32. $I d$.

33. Id.

34. Id.

35. Id.

36. Chris Smith, Minor League Baseball's Most Valuable Teams, Forbes (July 17, 2013, 7:44 AM), http://www.forbes.com/sites/chrissmith/2013/07/17/minor-league-baseballs-mostvaluable-teams [http://perma.cc/PM93-3UH8].

37. MiLB.com Frequently Asked Questions: The Business of MiLB, Minor LEAGUe BASEBALl (July 8, 2011), http://www.milb.com/milb/info/faq.jsp?mc=business, [http://perma.cc/ 7ZSF-DHYU].

38. $I d$.

39. Id.

40. Martin J. Greenberg \& Bryan M. Ward, Non-Relocation Agreements in Major League Baseball: Comparison, Analysis, and Best Practice Clauses, 21 MARQ. SpORTS L. Rev. 7, 7-8 (2010).

41. Id.

42. Id.

43. Andrew G. Clem, Major League Baseball Franchises: Historical Overview of Cities, Stadiums, and Owners, Clem's Baseball Blog (Nov. 3, 2012, 11:13 AM), http://www.and 
The Major League Rules govern franchise relocation at the major league level. ${ }^{44}$ Every major league organization has been granted a "home territory," giving the organization "protected territorial rights covering a specific geographic area. $" 45$ The Rules continue:

No Major or Minor League Club may play its home games within the home territory or within 15 miles from the boundary of the home territory of any other Minor League Clubs, and no Minor League Club may play its home games within the home territory or within 15 miles of the home territory of any Major League Club. ${ }^{46}$

Major League Baseball allows franchise relocation only in "the most dire circumstances where the local community has, over a sustained period, demonstrated that it cannot or will not support a franchise. ${ }^{.47}$ In order to relocate into another club's territory, a major league organization must give notice of its intention to relocate to the Commissioner of Baseball. ${ }^{48}$ The owners of the club wishing to relocate must prove they are able to sustain operations in the new territory for five years. ${ }^{49}$ The relocating club must also pay the existing club located in the territory an amount the "Commissioner deems appropriate under the circumstances. ${ }^{~} 50$ Finally, in accordance with the Major League Constitution, the relocation of any major league club requires approval by three-fourths of the major league clubs. ${ }^{51}$ Therefore, the ultimate decision of whether a club may relocate rests with the commissioner and other member clubs; the club seeking relocation has very little say.

2. Relocation Requirements for Minor League Clubs. - In contrast, Minor League Baseball has experienced franchise relocation and expansion with greater frequency. ${ }^{52}$ Specifically, between 1980 and 2001, 124 minor league teams

rewclem.com/Baseball/MLB_Franchises.html\#Relocations [http://perma.cc/7M9R-YECE].

44. See generally Office of the Comm'R of Baseball, Major League Rules (2008), available at http://bizofbaseball.com/docs/MajorLeagueRules-2008.pdf [http://perma.cc/EA4A6CWP] (last visited Dec. 30, 2015, 2:32 PM).

45. Id. at 130 (Rule 52(a)(1)).

46. Id. at 131 (Rule 52(a)(4)).

47. Jeffrey Gordon, Baseball's Antitrust Exemption and Franchise Relocation: Can a Team Move?, 26 Fordham URB. L.J. 1201, 1214 (1999) (quoting Letter from Thomas J. Ostertag, Gen. Counsel, Major League Baseball, to Jeffrey Gordon, J.D. Candidate, Fordham Univ. Sch. of Law (Nov. 6, 1997) (on file with the Fordham Urban Law Journal)).

48. OfFice of the COMm'R of BAseball, supra note 44, at 1 (Rule 1(a)(1)).

49. Id. (Rule 1(a)(2)).

50. Id. (Rule 1(a)(4)).

51. Major League Baseball Clubs, supra note 27, at 8 (art. V, § 2(b)(3)).

52. See Jeff Friedman, Antitrust Exemption Vital for Minor League Survival: MLB \& Parent Clubs Put Money Behind 1991 Stadium Standards, 1 DePaul J. SPorts L. \& ContemP. Probs. 118 (2003) (noting the "great disparity" between the number of relocations between minor league and major league franchises). 
relocated. ${ }^{53}$ The antitrust exemption is imperative for the survival of Minor League Baseball because it preserves the integral structure of professional baseball. $^{54}$

Minor league clubs must follow strict regulations before franchise relocation is allowed. ${ }^{55}$ First, a minor league franchise wishing to relocate must "notify in writing the Commissioner and the President of its Minor League Association of its intention to relocate at least 18 months before opening day of the season in which it would begin operations at the new location." ${ }^{, 56}$ After receiving written notification of a team's desire to relocate, "the President of the Club's Minor League Association shall require the Minor League Club proposing the relocation to establish that improved business operations (taking into account the quality of the playing facility and classification of play involved) and/or improved player development will be achieved at the proposed new location. ${ }^{57}$ If the President approves the relocation, the proposal is sent along to the Commissioner who reviews the decision, giving deference to the President. ${ }^{58}$ The Commissioner may overturn the President's approval for relocation if the Commissioner concludes:

(1) that the President of the Minor League Association failed in some material respect to adhere to the review and approval procedures in this Rule 53; (2) that the President . . . abused his or her discretion in approving the proposed relocation; or (3) that the relocation would not be in the best interests of Baseball. ${ }^{59}$

\section{Minor League Baseball's Pay Structure}

In addition to controlling franchise location, the Major League Rules control salary rates for minor league baseball players. ${ }^{60}$ The Rules require all contracts to be in the "form of the Minor League Uniform Contract" and "[a]1l Minor League Uniform Player Contracts between ... a Minor League Club and a player who has not previously signed a contract with a ... Minor League Club shall be for a term of seven Minor League playing seasons." ${ }^{61}$ Additionally, the Rules

53. See id. at 120 (citing a telephone interview with Steve Densa, Assistant Director of Media Relations for Minor League Baseball and an e-mail from Sandra Olmsted, Assistant to the General Counsel of Minor League Baseball).

54. See Samuel G. Mann, In Name Only: How Major League Baseball's Reliance on Its Antitrust Exemption Is Hurting the Game, 54 WM. \& MARY L. REv. 587, 620 (2012)("Eliminating or substantially altering the current minor league system would change the entire nature of professional baseball and the hundreds of small towns and cities across the country that currently serve as homes to minor league baseball clubs.").

55. See generally OfFicE OF THE COMM'R OF BASEBALL, supra note 44.

56. Id. at 137-38 (Rule 53(b)).

57. $I d$.

58. $I d$.

59. Id.

60. See generally id.

61. Id. at 21 (Rule 3(b)(2)). 
state:

The salary in each Minor League Uniform Player Contract between a Major League Club and a first-year player shall be the amount established by the Major Leagues for each Minor League classification of League ... On a pro rata basis, a first-year player must receive the minimum salary in a particular Minor League Classification for each day that the player spends on the Active List or Disabled List in that classification. $^{62}$

Under this directive, the typical minor league salary ranges from $\$ 1100$ per month for players in short-season leagues to $\$ 2150$ per month for players in Triple-A. ${ }^{63}$ This restriction on the amount of pay for minor leaguers is, in essence, a naked price-fixing arrangement among member clubs, making it ripe for antitrust challenge and posing a serious threat to baseball's antitrust exemption. ${ }^{64}$

\section{United States Antitrust LAws}

\section{A. Goals of Antitrust Laws}

In passing the Sherman Act, Congress intended "to protect consumers from the high prices and reduced output caused by monopolies and cartels." ${ }^{65}$ Compare this with the legislative history of the Clayton Act, which suggests the passage of this Act was "concerned with the protection of small businesses from the unfair or "exclusionary' practices of bigger firms." Ad Aditionally, Congress passed the Robinson-Patman Act, expanding the Clayton Act and further attempting to "protect small business from more efficient, larger firms." ${ }^{67}$ The U.S. Department of Justice states "the goal of antitrust law is to protect economic freedom and opportunity by promoting free and fair competition in the marketplace." ${ }^{\prime \prime}$ The

62. Id. at $22($ Rule $3(\mathrm{c})(2)(\mathrm{B}))$.

63. Josh Leventhal, Minor League Players Sue for Better Salaries, BASEBALl Am. (April 1, 2014), http://www.baseballamerica.com/minors/players-sue-for-better-salaries/, [http://perma. $\mathrm{cc} / \mathrm{XT} 2 \mathrm{Y}-\mathrm{TVRB}]$.

64. See infra Part IV.D. Restricting the mobility and wages of employees in industries other than professional baseball have been found to violate the antitrust laws. See, e.g., United States v. Adobe Sys., Inc., No. 1:10-cv-01629, 2011 WL 10883994 (D.C. Cir. March 18, 2011) (investigation finding agreements between Adobe, Apple, Google, Intel, and Pixar not to compete for employees per se illegal); In re High-Tech Emp. Antitrust Litig., 289 F.R.D. 555, 559 (N.D. Cal. 2013) (certifying a class action for "an 'overarching conspiracy' to eliminate competition amongst [Defendants] for skilled labor, with the intent and effect of suppressing the compensation and mobility of Defendants' employees").

65. Herbert Hovenkamp, Federal Antitrust Policy: The Law of Competition and Its Practice 59 (4th ed. 2011).

66. Id.

67. Id. at 67.

68. Antitrust Laws, U.S. DEP'T JUSTICE, http://www.justice.gov/atr/about/mission.html, [http://perma.cc/7GPD-2KEY] (last updated July 20, 2015). 
Sherman Antitrust Act prohibits restraints of trade that restrict competition. ${ }^{69}$ Given the cyclical nature of antitrust law, courts from various time periods have historically sought to advance different views regarding the underlying goals of antitrust law. ${ }^{70}$

1. Populist Era.- - Initially, the goal of antitrust law carried more of a sociopolitical underpinning. ${ }^{71}$ During this period - the Populist Era-antitrust policy was "openly hostile toward innovation and large scale development, and a zealous protector of the right of small business to operate independently." 72 Some thought that a "large number of small firms would yield lower prices than a relatively small number of larger firms." exemplified this goal when, in United States v. Aluminum Co. of America, he stated:

We have been speaking only of the economic reasons which forbid monopoly; but, as we have already implied, there are others, based upon the belief that great industrial consolidations are inherently undesirable, regardless of their economic results ... [A]mong the purposes of Congress in 1890 was a desire to put an end to great aggregations of capital because of the helplessness of the individual before them . . . Throughout the history of [the antitrust] statutes it has been constantly assumed that one of their purposes was to perpetuate and preserve, for its own sake and in spite of possible cost, an organization of industry in small units which can effectively compete with each other. ${ }^{74}$

Chief Justice Warren used a similar justification for the goal of antitrust law when he asserted that the Court 'cannot fail to recognize Congress' desire to promote competition through the protection of viable, small, locally owned businesses. Congress appreciated that occasional higher costs and prices might result from the maintenance of fragmented industries and markets. It resolved these competing considerations in favor of decentralization., ${ }^{, 75}$

69. Susan Marie Kozik, Note, National Collegiate Athletic Association v. Board of Regents of the University of Oklahoma and University of Georgia Athletic Association 104 S.Ct. 2948 (1984), 61 ChI.-Kent L. ReV. 593, 593 (1985).

70. See generally HovenKAMP, supra note 65, at 65-68 (providing an overview of antitrust policy and highlighting the different interpretations of the antitrust laws espoused by courts throughout the twentieth century).

71. See Joshua D. Wright \& Douglas H. Ginsburg, The Goals of Antitrust: Welfare Trumps Choice, 81 Fordham L. Rev. 2405, 2405 (2013) (noting the Supreme Court interpreted the antitrust laws to "reflect a hodgepodge of social and political goals, many with an explicitly anticompetitive bent, such as protecting small traders from more efficient rivals"); see also United States v. Trans-Missouri Freight Ass'n, 166 U.S. 290, 323 (1897) (concluding the purpose of the antitrust laws is to protect "small dealers and worthy men").

72. HOVENKAMP, supra note 65 , at 68 .

73. Id. at 70 .

74. United States v. Aluminum Co. of Am., 148 F.2d 416, 428-29 (2d Cir. 1945).

75. Brown Shoe Co., Inc. v. United States, 370 U.S. 294, 344 (1962). 
2. Current Antitrust Goals. - With the decline of the Populist Era came a shift in the view of what antitrust law should ultimately be used to achieve. ${ }^{76}$ Economic efficiency came to rise as the primary goal of antitrust legislation and the Reagan Administration heavily advocated for this goal. ${ }^{77}$ Economic efficiency has two components: productive efficiency and allocative efficiency. ${ }^{78}$ Generally, productive efficiency is a product of a firm's research and development. ${ }^{79}$ It is "a fraction in which the value of a firm's output is the numerator and the value of its inputs is the denominator; the higher this ratio, the more efficient the firm." ${ }^{" 80}$ The second component of economic efficiency-allocative efficiency-looks at the efficiency of markets as a whole as measured by the Pareto criterion ${ }^{81}$ Optimal allocative efficiency is attained in competitive markets. ${ }^{82}$ With economic efficiency as the goal, antitrust policy seeks "to maximize net efficiency gains and, when this is accomplished, no antitrust violation can be found." ${ }^{\prime 3}$ Along with members of the Reagan Administration, Judge Richard Posner has been a proponent of economic efficiency as the goal of antitrust law. ${ }^{84}$ This view of promoting economic efficiency creates a "dichotomy" between efficiency maximization "equity objectives" (i.e., political and social goals) and places these equity objectives outside the purview of antitrust. ${ }^{85}$ Economic efficiency-and antitrust policy in general-seeks to protect “"competition,' not 'competitors."

In looking at the legislative history and recent Supreme Court cases, John Kirkwood argued consumer protection is the only rational goal of antitrust law ${ }^{87}$

76. Vivek Ghosal, Regime Shift in Antitrust, ReSearchGate (2004), https://www. researchgate.net/publication/253737921_Regime_Shifts_in_Antitrust [perma.cc/8KMF-UN75] (discussing the shift in antitrust philosophy driven by Chicago School economic theory).

77. See Robert E. Taylor, A Talk with Antitrust Chief William Baxter, Wall St. J., Mar. 4, 1982, at 28 (noting William Baxter's, President Reagan's Assistant Attorney General for Antitrust, comment that "The sole goal of antitrust is economic efficiency").

78. HOVENKAMP, supra note 65 , at 71 .

79. Id.

80. Id.

81. Id. at $71,83-84$.

82. Id. at 71.

83. Id.; see also Robert H. Bork, The Antitrust Paradox: A Policy at War with ITSELF 91 (Basic Books 1993) ("The whole task of antitrust can be summed up as the effort to improve allocative efficiency without impairing productive efficiency so greatly as to produce either no gain or a net loss in consumer welfare.”).

84. See Richard A. Posner, Antitrust law ix (The Free Press 2d ed. 2001) ("Almost everyone professionally involved in antitrust today-whether as litigator, prosecutor, judge, academic, or informed observer ... agrees that the only goal of the antitrust law should be to promote economic welfare ....”).

85. Kenneth G. Elzinga, The Goals of Antitrust: Other than Competition and Efficiency, What Else Counts?, 125 U. PA. L. REV. 1191, 1192 (1977).

86. Edward T. Swaine, “Competition, Not Competitors," Nor Canards: Ways of Criticizing the Commission, 23 U. PA. J. INT’L ECON. L. 597, 599 (2002).

87. Id. 
Elaborating on his interpretation of the goal of antitrust law, Kirkwood explained, "The fundamental goal of antitrust ... is to protect consumers in the relevant market from anticompetitive behavior that exploits them - that unfairly transfers their wealth to firms with market power-not to increase the total wealth of society." $" 88$ Furthermore, advocates for the prevention of wealth transfers and consumer protection claim Congress passed the antitrust laws with a distributive goal in mind, namely "preventing unfair acquisitions of consumers' wealth by firms with market power." 89

Today, a majority of antitrust judges, scholars, and practitioners assert the current goal of antitrust law is the maximization of consumer welfare. ${ }^{90}$ The Supreme Court $^{91}$ and academics ${ }^{92}$ recognize the maximization of consumer welfare as "at least the primary goal of antitrust enforcement policy." ${ }^{93}$ Robert Bork argued courts have wrongly applied economic concepts to antitrust cases for decades and called for a reform of antitrust analysis with the main focus on consumer welfare maximization:

A consumer-oriented law must employ economic theory to judge which market structures and practices are harmful and which beneficial. Modern antitrust has performed this task very poorly. . . [C]ourts, and particularly the Supreme Court, have failed to understand and give proper weight to the crucial concept of business efficiency. Since productive efficiency is one of the two opposing forces that determine the degree of consumer well-being ... this failure has skewed the legal doctrine disastrously. Business efficiency necessarily benefits consumers by lowering the costs of goods and services or by increasing the value of the product or service offered; this is true whether the business unit is a competitor or a monopolist. ${ }^{94}$

Although never explicitly pronouncing consumer welfare as the current goal of antitrust law, "courts almost invariably apply a consumer welfare test." 95

88. Id.

89. R.H. Lande, Wealth Transfers as the Original and Primary Concern of Antitrust: The Efficiency Interpretation Challenged, 34 Hastings L.J. 65, 70 (1982).

90. Gary R. Roberts, Sports Leagues and the Sherman Act: The Use and Abuse of Section 1 to Regulate Restraints on Intraleague Rivalry, 32 UCLA L. REV. 219, 220 (1984); see Myron C. Grauer, Recognition of the National Football League as a Single Entity Under Section 1 of the Sherman Act: Implications of the Consumer Welfare Model, 82 MicH. L. REV. 1, 7-14 (1983) (arguing consumer welfare maximization is the proper goal of antitrust law).

91. See Reiter v. Sonotone Corp., 442 U.S. 330, 343 (1979) (noting the congressional floor debates "suggest that Congress designed the Sherman Act as a "consumer welfare prescription"').

92. See Roberts, supra note 90, at 220 n.4 ("There is general agreement that the paramount economic objective of antitrust is to promote consumer welfare.") (quoting S.C. OPPENHEIM ET AL., FEDERAL ANTITRUST LAW 9-11 (4th ed. 1981)).

93. Id.

94. Bork, supra note 83 , at 7-8.

95. See Herbert Hovenkamp, Implementing Antitrust's Welfare Goals, 81 FordHAM L. REV. 


\section{B. Antitrust Analysis}

With these goals in mind, courts have traditionally applied two types of analysis in determining whether a restraint of trade is unreasonable and thus triggers a violation of the Sherman Act: the "per se" analysis and the "Rule of Reason" analysis. ${ }^{96}$

1. Per Se Illegality.- - Historically, courts have held certain practices to be per se violations of antitrust law. ${ }^{97}$ This per se analysis was first articulated in the Supreme Court's decision in Standard Oil v. United States..$^{98}$ An agreement is per se illegal when its "nature and necessary effect are so plainly anticompetitive that no elaborate study of the industry is needed to establish their illegality." 99 Expressed in economic terms, a per se rule applies when "the practice facially appears to be one that would always or almost always tend to restrict competition and decrease output." ${ }^{100}$ In more recent decisions, courts have somewhat narrowed-and in some cases overruled - the per se approach to antitrust cases. ${ }^{101}$

2. Rule of Reason Analysis.-Like the per se analysis, the Supreme Court developed the Rule of Reason in Standard Oil. ${ }^{102}$ "The [R]ule of [R]eason requires the fact-finder to decide whether under all the circumstances of the case the restrictive practice imposes an unreasonable restraint on competition." ${ }^{\text {103 }}$ In applying the Rule of Reason analysis, a court must conduct "a thorough investigation of the industry at issue and a balancing of the arrangement's positive and negative effects on competition. ${ }^{104}$ In order for an antitrust violation

2471, 2476 (2013).

The case law generally assigns and weighs presumptions depending on the court's opening assessment of the degree of danger that a restraint imposes. If a category of practices is strongly regarded as benign, plaintiffs will face stringent proof requirements, and vice versa. Second, however, if the evidence in a particular case indicates that a challenged practice facilitates the exercise of market power, resulting in output that is actually lower and prices that are actually higher, then tribunals uniformly condemn the restraint without regard to offsetting efficiencies. . In sum, courts almost invariably apply a consumer welfare test.

Id. at 2475-76.

96. See Nat'1 Soc'y of Prof'1 Eng'rs v. United States, 435 U.S. 679 (1978) (laying out the two different modes of antitrust analysis).

97. Guide to Antitrust Laws, WASH. St. OfF. AtT'y Gen., http://www.atg.wa.gov/guideantitrust-laws [perma.cc/QYH5-MMLL] (last visited Jan. 16, 2016).

98. See Standard Oil Co. v. United States, 221 U.S. 1 (1911) (recognizing certain restraints immediately ended the Rule of Reason analysis).

99. Nat'l Soc'y of Prof'l Eng'rs, 435 U.S. at 692.

100. Broad. Music, Inc. v. Columbia Broad. Sys., Inc., 441 U.S. 1, 19-20 (1979).

101. See Kozik, supra note 69 , at 596 (discussing the trend by courts of expanding the analysis required under the per se approach).

102. Standard Oil, 221 U.S. 1.

103. Arizona v. Maricopa Cty. Med. Soc'y, 457 U.S. 332, 343 (1982).

104. Northrop Corp. v. McDonnell Douglas Corp., 705 F.2d 1030, 1050 (9th Cir. 1983). 
to occur under the Rule of Reason analysis, "the restraint's harm to competition [must] outweigh[] its pro-competitive effects." ${ }^{\text {. } 105}$ The plaintiff carries the initial burden of proving the alleged restraint results in "significant anticompetitive effects" within a "relevant market." 106 If the plaintiff meets this requirement, the burden shifts to the defendant who must produce evidence of the restraint's "procompetitive effects." 107 In rebuttal, the plaintiff is then required to show that "any legitimate [procompetitive] objectives can be achieved in a substantially less restrictive manner." 108

\section{Condemnable Business Practices Under the Antitrust Laws ${ }^{109}$}

Several practices subject to antitrust scrutiny may be implicated by professional baseball's relocation requirements and wage structure.

1. Price Fixing.-Generally, price fixing is an agreement with a competitor to compete less vigorously. ${ }^{110}$ There are two basic types of price fixing: horizontal price fixing and vertical price fixing. Horizontal price fixing occurs when competitors at the same level of the distribution chain agree to set prices at certain levels. ${ }^{111}$ In United States v. Socony-Vacuum Oil Co., the Court held a pricefixing agreement between major oil companies to be per se illegal. ${ }^{12}$ However, the Supreme Court backed away from this hardline approach of per se illegality

105. Tanaka v. Univ. of S. Cal., 252 F.3d 1059, 1063 (2001) (citing Hairston v. Pac. 10 Conference, 101 F.3d 1315, 1319 (1996)).

106. $I d$.

107. Id.

108. Id.

109. This section focuses solely on antitrust concepts relevant to professional baseball and does not cover all practices that may be condemnable under the antitrust laws. For a discussion of other antitrust concepts, see generally HovENKAMP, supra note 65, at 290-311 (monopolies), 31523 (unilateral refusals to deal), 370-89 (predatory pricing), 425-32 (vertical mergers), 478-88 (exclusive dealing), 514-25 (resale price maintenance), 541-48 (horizontal mergers).

110. Paul Gift, Price Fixing and Minimum Resale Price Restrictions Are Two Different Animals, 12 GRAZIADIO BUS. REV. (2009), available at https://gbr.pepperdine.edu/2010/08/pricefixing-and-minimum-resale-price-restrictions-are-two-different-animals/ [http://perma.cc/BVS3XAT8].

111. Id. Vertical price fixing, although not pertinent to the discussion, occurs "when a manufacturer tells its dealer or distributor the minimum price at which it must resell its goods." John A. Washburn, Vertical Minimum Price Fixing-Still A Problem?, Gould \& RATNER LLP (2011), http://www.gouldratner.com/Assets/News/Vertical\%20Minimum\%20Pricing.pdf [http://perma.cc/4XC7-QQ9Z].

112. United States v. Socony-Vacuum Oil Co., 310 U.S. 150, 218 (1940). The Court reasoned:

$[F]$ or over forty years this Court has consistently and without deviation adhered to the principle that price-fixing agreements are unlawful per se under the Sherman Act and that no showing of so-called competitive abuses or evils which those agreements were designed to eliminate or alleviate may by interposed as a defense.

Id. at 218 . 
for horizontal price fixing. ${ }^{113}$

If subject to antitrust scrutiny (i.e., not exempt), professional baseball's pay structure would be in violation of the antitrust laws as a horizontal price-fixing agreement. Under this theory, the constituent professional clubs have agreed with each other to set prices that will be paid to minor league players. Specifically, this wage structure "results in the per se antitrust violation of price fixing, at artificially low levels, the compensation minor league players can receive, by preventing minor league players from offering their services to competing teams who, in a competitive market, would offer them more for their services." 114

2. Market Allocation.-Like price fixing, market allocation can be either horizontal or vertical in nature. Horizontal market allocation occurs when competitors at the same level of the distribution chain agree to divide the specific market among themselves. ${ }^{115}$ Vertical market allocation takes place when firms at different levels of the distribution chain agree to divide a specified market. ${ }^{116}$ Although horizontal market allocation has traditionally been analyzed under a per se approach ${ }^{117}$ the legality of vertical market allocation is determined under the Rule of Reason. ${ }^{118}$

Professional baseball's location requirements are an example of horizontal market allocation, subjecting it to per se analysis if not for professional baseball's

113. See infra Part IV.B (discussing Broadcast Music, Inc. v. Columbia Broadcasting Systems, Inc. and the Court's shift away from a per se approach when dealing with price fixing). Vertical price fixing is analyzed under the Rule of Reason. See Leegin Creative Leather Prods. v. PSKS, Inc., 551 U.S. 887, 907 (2007) (overruling Dr. Miles Medical Co. and stating vertical price fixing is "to be judged according to the Rule of Reason").

114. Complaint at 21, Miranda v. Selig, No. 14-cv-05349-HSG, 2015 WL 5357854 (N.D. Cal. Sept. 14, 2015), appeal docketed, No. 15-16938 (9th Cir. 2015).

115. Price Fixing, Bid Rigging, and Market Allocation Schemes: What They Are and What to Look For, U.S. DEP'T JUSTICE, http://www.justice.gov/atr/public/guidelines/211578.htm [http://perma.cc/5HY6-BEDF] (last updated June 25, 2015).

116. Jayma M. Meyer, Relaxation of the Per Se Mantra in the Vertical Price Fixing Arena, 68 S. CAL. L. REV. 73, 76 n.2 (1994).

117. See United States v. Sealy, Inc., 388 U.S. 350, 357 (1967) (finding an exclusive right to sell Sealy mattress products to be a per se illegal "aggregation of trade restraints."); see also United States v. Topco Assocs., 405 U.S. 596, 608 (1972) (holding "it is clear that the restraint . . is a horizontal one, and, therefore, a per se violation of [Section] 1."). In dissent in Topco, Justice Burger advocated for a Rule of Reason analysis, requiring "consideration of the relevant economic realities in the light of the basic policy and goals of the Sherman Act." Id. at 615. Although the Supreme Court has not narrowed the use of the per se approach in horizontal market allocation cases, the Seventh Circuit has effectively transitioned to a Rule of Reason approach in these situations. See Polk Bros., Inc. v. Forest City Enters., Inc., 776 F.2d 185 (7th Cir. 1985) (holding the Rule of Reason analysis applies when determining whether horizontal market allocation violates antitrust law).

118. See Cont'l Television, Inc. v. GTE Sylvania, Inc., 433 U.S. 36 (1977) (holding the Rule of Reason approach used prior to United States v. Arnold, Schwinn \& Co., 388 U.S. 365 (1967), is the correct mode of analysis). 
exemption from antitrust laws. Member clubs "agree to divide the relevant market by assigning an exclusive territory to each Club." 119 The clubs then "expressly agree not to compete in the other Clubs' exclusive territories[,] . . creat[ing] regional monopolies that protect the Clubs from competition in their respective local areas. " ${ }^{120}$ Although baseball's exemption was upheld in San Jose, if a future challenge to baseball's location requirements comes out differently, teams would have the ability to move freely into other teams' territories. As a result, smallmarket teams would flee to larger cities where they can earn higher revenues, decreasing consumer welfare in the cities that lose their teams.

\section{Supreme Court’s Baseball “Trilogy” AND Other Professional BASEBALl CASES ${ }^{121}$}

\section{A. The Creation and Continued Affirmation of Baseball's Antitrust Exemption: Federal Baseball, Toolson, and Flood}

In the beginning days of professional baseball, the Federal League and National League competed for the best players. ${ }^{122}$ The Federal League lobbied the top players, including Ty Cobb, Mordecai Brown, and Hal Chase, in an attempt to persuade them to jump ship and leave the National League. ${ }^{123}$ In response, the National League allegedly conspired to create a monopoly over the business of baseball by "buying up some of the [Federal League] constituent clubs and in one way or another inducing all those clubs except the plaintiff to leave their League." ${ }^{24}$ The Federal League claimed the National League's actions amounted to a "conspir[acy] to monopolize the base ball [sic] business" in violation of the antitrust laws. ${ }^{125}$ Admitting the inevitable crossing of state lines by players to provide these exhibitions, Justice Holmes nevertheless ruled this transport was "a mere incident, not the essential thing." ${ }^{26}$ Justice Holmes held "[t]he business

119. Complaint at 4, City of San Jose v. Office of the Comm'r of Baseball, No. C-13-02787, 2013 WL 5609346 (N.D. Cal. June 18, 2013), aff'd, 776 F.3d 686 (9th Cir. 2015), cert. denied, 136 S. Ct. 36 (2015).

120. Id. at 4-5.

121. This section focuses specifically on antitrust challenges in Major League Baseball. However, this is not to suggest that other professional sports leagues have not come under antitrust scrutiny. In fact, several major professional sports leagues have been subjected to antitrust analysis. See Radovich v. Nat'l Football League, 352 U.S. 445 (1957) (NFL); United States v. Int'1 Boxing Club, 348 U.S. 236 (1955) (boxing); Nat'l Basketball Assoc. v. SDC Basketball Club, Inc., 815 F.2d 562 (1987) (NBA); S.F. Seals, Ltd. v. Nat'l Hockey League, 379 F. Supp. 966 (C.D. Cal. 1974) (NHL).

122. Roger I. Abrams, Before the Flood: The History of Baseball's Antitrust Exemption, 9 MARQ. SPORTS L.J. 307, 307 (1999).

123. Id.

124. Fed. Baseball Club of Balt., Inc. v. Nat'1 League of Prof'1 Baseball Clubs, 259 U.S. 200, 207 (1922).

125. $I d$.

126. Id. at 209. 
is giving exhibitions of base ball [sic], which are purely state affairs. ${ }^{127} \mathrm{He}$ analogized professional baseball to a law firm, saying, "a firm of lawyers sending out a member to argue a case ... does not engage in such [interstate] commerce because the lawyer ... goes to another State." ${ }^{128}$ As a result, the Supreme Court created an antitrust exemption for professional baseball. ${ }^{129}$

The Supreme Court's ruling in Federal Baseball went unchallenged for over thirty years before the antitrust exemption was tested. ${ }^{130}$ In 1953, the Supreme Court decided Toolson v. New York Yankees, Inc., in which a minor league player challenged the "reserve clause" as violating antitrust law. ${ }^{131}$ "The reserve system ... centers in the uniformity of player contracts; the confinement of the player to the club that has him under the contract; the assignability of the player's contract; and the ability of the club annually to renew the contract unilaterally, subject to a stated salary minimum." ${ }^{\text {32 }}$ Specifically, the reserve system "was a provision in baseball contracts that prevented players from signing with other clubs, even after their contracts had expired, without the express consent of the club they played for." 133 It "served to bind every player to his club indefinitely, because the clause was renewed simply by renewing the contract for the succeeding season." ${ }^{134}$ In a terse, per curiam opinion, the Supreme Court did not reconsider the issues and affirmed Justice Holmes' decision in Federal Baseball. ${ }^{135}$ Specifically, the Court stated, "If there are evils in this field which now warrant application to it of the antitrust laws it should be by legislation." 136

In the final case of the Supreme Court "Baseball Trilogy," the Court, with Justice Blackmun authoring the opinion, once again ruled that professional baseball was exempt from antitrust laws. ${ }^{137}$ Similar to the previous challenge in Toolson, Flood v. Kuhn involved a challenge to MLB's reserve system, claiming the system violated antitrust laws. ${ }^{138}$ Curt Flood was a center fielder for the St. Louis Cardinals from 1958 through $1969 .{ }^{139}$ Flood excelled during his years in

127. Id. at 208 .

128. Id. at 209.

129. James D. Weinberger, Baseball Trademark Licensing and the Antitrust Exemption: An Analysis of New York Yankees Partnership v. Major League Baseball Enterprises, Inc., 23 CoLUM.VLA J.L. \& ARTS 75 (1999).

130. Id.

131. See generally Toolson v. N.Y. Yankees, Inc., 346 U.S. 356 (1953).

132. Flood v. Kuhn, 407 U.S. 258, 260 n.1 (1972).

133. City of San Jose v. Office of the Comm'r of Baseball, 776 F.3d 686, 689 n.4 (9th Cir. 2015), cert. denied, 136 S. Ct. 36 (2015).

134. Daniel S. York, The Professional Sports Community Protection Act: Congress'Best Response to Raiders?, 38 HASTINGS L.J. 345, 353 n.48 (1987).

135. Toolson, 346 U.S. at 357.

136. Id.

137. Flood, 407 U.S. at 258.

138. Id. at 259.

139. Id. at 264. 
St. Louis. ${ }^{140}$ However, after the 1969 season, without his consent or consultation, St. Louis traded Flood to the Philadelphia Phillies. ${ }^{141} \mathrm{He}$ then brought suit, claiming violation of antitrust law. ${ }^{142}$ For the third time in fifty years, the Supreme Court adhered to its decision in Federal Baseball. ${ }^{143}$ The Court recognized professional baseball is involved in interstate commerce, baseball is an "an exception and an anomaly," 144 and the decision might be "unrealistic, inconsistent, or illogical." ${ }^{\prime 45}$ Nonetheless, the Court reiterated if a change is to be made, it should be done by Congress. ${ }^{146}$

\section{B. A Rationale So Far Removed}

Today, the Supreme Court's rationale in Federal Baseball for the creation of baseball's antitrust exemption is so far removed from reality. Federal Baseball is a holdover from the Populist Era when the goals of antitrust law were other than that of pure economic efficiency. No one can legitimately argue that baseball games are "purely state affairs." 147 Take, for example, MLB's National League Central Division, which is comprised of teams from five different states-Wisconsin (Milwaukee Brewers), Illinois (Chicago Cubs), Missouri (St. Louis Cardinals), Ohio (Cincinnati Reds), and Pennsylvania (Pittsburgh Pirates). ${ }^{148}$ During the course of the season, each of these teams travels out-ofstate multiple times to play the others. ${ }^{149}$ Therefore, baseball games clearly implicate interstate affairs, and the game's exemption from federal antitrust laws is "an aberration confined to baseball." ${ }^{50}$ This rationale, which courts continue to adhere to, makes baseball's antitrust exemption prone to review. As such, in order to maintain professional baseball's current structure, preservation of the antitrust exemption is required.

\section{A Departure from Precedent}

Even with the "Trilogy" as precedent, two courts have expressly limited baseball's antitrust exemption. ${ }^{151}$ Although no courts have followed the decisions

140. See id. (highlighting Curt Flood's achievements on the field as a member of the St. Louis Cardinals).

141. Id. at 265 .

142. Id.

143. $I d$. at 284 .

144. Id. at 282 .

145. Id. (quoting Radovich v. Nat'l Football League, 352 U.S. 445, 452 (1957)).

146. Id. at 284.

147. See Fed. Baseball Club of Balt., Inc. v. Nat'l League of Prof'l Baseball Clubs, 259 U.S. 200, 208 (1922).

148. Standings, MLB.cOM, http://mlb.mlb.com/mlb/standings/\#20151004 [perma.cc/D3V3WSKB] (last visited Jan. 16, 2016).

149. Id.

150. Flood, 407 U.S. at 282.

151. See Piazza v. Major League Baseball, 831 F. Supp. 420, 438 (E.D. Pa. 1993) (limiting 
in Piazza and Butterworth, these two rulings could lay the groundwork for a challenge - and possible repeal—of baseball's antitrust exemption. ${ }^{152}$

1. Piazza v. Major League Baseball. - The U.S. District Court for the Eastern District of Pennsylvania was the first court to limit baseball's antitrust exemption. ${ }^{153}$ The lawsuit originated from a failed attempt by Vincent Piazza and his business partner, Vincent Tirendi, to purchase the San Francisco Giants and relocate the club to Tampa Bay, Florida. ${ }^{154}$ Piazza and Tirendi executed a Letter of Intent with Robert Lurie, the Giants' owner, to purchase the Giants for $\$ 115$ million. ${ }^{155}$ Lurie was not to entertain offers from other potential buyers and was to use his "best efforts" to obtain approval of the sale and relocation of the Giants to Tampa. ${ }^{156}$ In conformance with MLB requirements, Piazza and Tirendi submitted an application to MLB for approval of the sale and relocation. ${ }^{157}$ Major League Baseball conducted background checks on Piazza and Tirendi. ${ }^{158}$ The results raised "serious question[s]" about the two men and thus Major League Baseball rejected the proposed sale of the Giants. ${ }^{159}$ As a result of the rejection, a new offer of $\$ 100$ million was made to buy the Giants and keep them in San Francisco, which was accepted by MLB. ${ }^{160}$

Piazza and Tirendi sued MLB for violation of the antitrust laws, and MLB responded by asserting an exemption from antitrust liability. ${ }^{161}$ The court expressly rejected MLB's assertion, holding any antitrust exemption enjoyed by MLB is limited to the reserve clause. ${ }^{162}$ In reaching this conclusion, the court conducted a thorough analysis of the Supreme Court's "Trilogy"163 and found that each of those cases specifically involved the reserve clause. ${ }^{164}$ This decision has been met with mixed reviews ${ }^{165}$ and has failed to carry the weight of the day in

the exemption to the reserve clause); Butterworth v. Nat'1 League of Prof'l Baseball Clubs, 644 So. 2d 1021, 1025 (Fla. 1994) (same).

152. See Y. Shukie Grossman, Antitrust and Baseball-A League of Their Own, 4 FordHAM InTELl. Prop. Media \& EnT. L.J. 563, 565 (1993) (characterizing the Piazza decision as "perhaps the most formidable challenge to Baseball's exemption in recent years").

153. See Piazza, 831 F. Supp. at 438.

154. Id. at 421 .

155. Id. at 422 .

156. Id.

157. Id.

158. Id.

159. Id.

160. Id. at 423 .

161. Id. at 424 .

162. Id. at 440 .

163. See Justin B. Bryant, Analyzing the Scope of Major League Baseball's Antitrust Exemption in Light of San Jose v. Office of the Commissioner of Baseball, 89 Notre DAME L. REV. 1841, 1853 (2014) (characterizing the Piazza decision as "[t]he most thorough district court analysis considering the scope of the baseball exemption").

164. See Piazza, 831 F. Supp. at 433-35 (discussing each of the prior Supreme Court cases).

165. Compare Charles Matthew Burns, The Scope of Major League Baseball's Antitrust 
analyzing professional baseball antitrust cases. ${ }^{166}$

2. Butterworth v. National League of Professional Baseball Clubs.-One year after the U.S. District Court for the Eastern District of Pennsylvania ruled baseball's antitrust exemption applied only to the reserve clause, ${ }^{167}$ the Supreme Court of Florida - in a case arising from the same botched relocation effort of the Giants to Tampa Bay-held the exemption does not cover the sale and location of baseball franchises. ${ }^{168}$ In Butterworth, the Florida Attorney General attempted to issue antitrust civil investigative demands against the National League. ${ }^{169}$ After the Fifth District Court of Appeals of Florida quashed the lawsuit, the Florida Supreme Court held the Flood decision "seriously undercuts the precedential value of both Federal Baseball and Toolson." 170 Furthermore, the court stated, "Based upon the language and the findings in Flood, we come to the same conclusion as the Piazza court: baseball's antitrust exemption extends only to the reserve system." 171

\section{San Jose Strikes Out}

The City of San Jose was the most recent challenger to MLB's antitrust exemption. ${ }^{172}$ The Oakland Athletics wanted to move to San Jose in hopes of generating more revenue and fan support for the club. ${ }^{173}$ However, San Jose is located "within the exclusive operating territory of the San Francisco Giants," requiring approval of at least three-quarters of major league clubs for the move

Exemption, 24 Stetson L. REV. 495, 532-34 (1995) (arguing the court correctly decided Piazza); Latour Rey Lafferty, The Tampa Bay Giants and the Continuing Vitality of Major League Baseball's Antitrust Exemption: A Review of Piazza v. Major League Baseball, 21 FLA ST. U. L. REV. 1271, 1288 (1994) (same); Mitchell Nathanson, The Irrelevance of Baseball's Antitrust Exemption: A Historical Review, 58 Rutgers L. Rev. 1, 6 (2005) (same); Martin M. Tomlinson, The Commissioner's New Clothes: The Myth of Major League Baseball's Antitrust Exemption, 20 St. Thomas L. Rev. 255, 310 (same), with John W. Guarisco, "Buy Me Some Peanuts and Cracker Jack, " but You Can't Buy the Team: The Scope and Future of Baseball's Antitrust Exemption, 1994 U. ILL. L. REv. 651, 661-62 (1994) (arguing the court wrongfully decided Piazza); Joseph J. McMahon, Jr. \& John P. Rossi, A History and Analysis of Baseball's Three Antitrust Exemptions, 2 Vill. SpORTs \& ENT. L.F. 213, 255-56 (1995) (same).

166. See Nathaniel Grow, Defining the "Business of Baseball": A Proposed Framework for Determining the Scope of Professional Baseball's Antitrust Exemption, 44 U.C. DAVIS L. REV. 557, 589 (2010) (citations omitted) ("The decision has generated a split of opinion among scholars, with some commentators concluding that the case was properly decided, while others have suggested that the opinion may be 'intellectually infirm' or 'flawed."').

167. Piazza, 831 F. Supp. at 438.

168. Butterworth v. Nat'1 League of Prof'1 Baseball Clubs, 644 So. 2d 1021, 1022 (Fla. 1994).

169. Id.

170. Id. at 1025 .

171. Id.

172. City of San Jose v. Office of the Comm'r of Baseball, 776 F.3d 686, 686 (9th Cir. 2015), cert. denied, 136 S. Ct. 36 (2015).

173. Id. at 688 . 
to happen. ${ }^{174}$ Major League Baseball never approved the relocation, and the Athletics filed suit for violation of federal antitrust law. ${ }^{175}$ Citing the historic antitrust exemption for professional baseball, the district court dismissed San Jose's case, and San Jose appealed to the Ninth Circuit. ${ }^{176}$ The Ninth Circuit ruled that "antitrust claims against MLB's franchise relocation policies are in the heartland of those precluded by Flood's rationale." 177 The court went on to explain:

The scope of the Supreme Court's holding in Flood plainly extends to questions of franchise relocation. San Jose is, at bottom, asking us to deem Flood wrongly decided, and that we cannot do. Only Congress and the Supreme Court are empowered to question Flood's continued vitality, and with it, the fate of baseball's singular and historic exemption from the antitrust laws. ${ }^{178}$

In October 2015, the Supreme Court denied certiorari to the City of San Jose, officially ending the challenge to MLB's antitrust exemption-at least for now. ${ }^{179}$ For most, this denial came as no surprise. ${ }^{180}$ Aside from the fact that most courts-including the Supreme Court-have rejected challenges to baseball's antitrust exemption out of hand, San Jose presented other issues that made the case an unattractive one for the Supreme Court to take. ${ }^{181}$ San Jose struck out in its attempt to overturn baseball's antitrust exemption, but two cases are making their way through the court system that have the potential to provide real challenges to the historic exemption-and Minor League Baseball. ${ }^{182}$ The two cases challenge Minor League Baseball's pay structure. ${ }^{183}$ The first case, Miranda v. Selig, challenges the structure on antitrust grounds, ${ }^{184}$ and the second case, Senne v. Kansas City Royals Baseball Corp., on grounds that the pay structure

174. Id; see also Major League Baseball Clubs, supra note 27, at 8 (art. V, § 2(b)(3)).

175. City of San Jose, 776 F.3d at 688.

176. $I d$.

177. Id. at 691 .

178. Id. at 692 .

179. City of San Jose v. Office of the Comm'r of Baseball, 136 S. Ct. 36 (2015).

180. See Nathaniel Grow, San Jose Strikes Out at the U.S. Supreme Court, FANGRAPHS (Oct. 5, 2015), http://www.fangraphs.com/blogs/san-jose-strikes-out-at-the-u-s-supreme-court/ [http:// perma.cc/296T-8HL2].

181. Id. (noting "a potentially fatal procedural flaw in San Jose's case, namely the city's questionable legal standing-to-sue (the requirement that a plaintiff have a personal stake in the outcome of an actual — not merely hypothetical - legal case or controversy)" may have persuaded the Court to deny certiorari).

182. See generally Senne v. Kansas City Royals Baseball Corp., No.14-CV-00608-JCS, 2015 WL 6152476, at*1 (N.D. Cal. Oct. 20, 2015); Miranda v. Selig, No.14-CV-05349-HSG, 2015 WL 5357854, at*1 (N.D. Cal. Sept. 14, 2015), appeal docketed, No.15-16938 (9th Cir. 2015).

183. Senne, 2015 WL 6152476, at*1; Miranda, 2015 WL 5357854, at*1.

184. Miranda, 2015 WL 5357854, at*1. 
violates the Fair Labor Standards Act. ${ }^{185}$ The U.S. District Court for the Northern District of California dismissed Miranda based on the Supreme Court's "Trilogy," 186 while Senne was recently granted class certification. ${ }^{187}$

It is clear that if a change to baseball's antitrust exemption is to occur, it must come either from Congress or the Supreme Court. ${ }^{188}$ Congress has refused to address the issue since the passing of the Curt Flood Act, so it looks as though any change would be up to the discretion of the Supreme Court. ${ }^{189}$ Because of Supreme Court Rule 10, which governs considerations for review on certiorari, Miranda very well could be granted certiorari and present a laudable challenge to the exemption. ${ }^{190}$ Supreme Court Rule 10 reiterates that the granting of certiorari is based on judicial discretion and will only be done for "compelling reasons." ${ }^{.191}$ Specifically, in determining whether to grant certiorari, the Supreme Court considers whether a "state court or a United States court of appeals has decided an important question of federal law that has not been, but should be, settled by this Court." 192 With respect to Miranda, the important question of federal law the district court decided was whether baseball's antitrust exemption applies to the pay structure of minor league baseball. ${ }^{193}$ The district court relied on baseball's exemption, but no other court has addressed whether the exemption extends to minor league players' compensation. ${ }^{194}$ Additionally, a compelling reason for the Court to grant certiorari would be to reexamine whether professional baseball, like every other industry, should be subject to the antitrust

185. Senne, 2015 WL 6152476 , at*1. Although it would not be a direct challenge to baseball's antitrust exemption, if a court were to rule minor league baseball's pay structure violates the FLSA, the impact on the structure of minor league baseball as a whole would be tremendous.

186. Miranda, 2015 WL 5357854, at*2-3.

Plaintiffs have a persuasive policy argument that the defendants [Major League Baseball] should not be afforded carte blanche to restrict the pay and mobility of minor league players without answering to the federal antitrust laws . . . But that policy argument must be made to Congress or the Supreme Court. "Only Congress and the Supreme Court are empowered to question Flood's continued vitality, and with it, the fate of baseball's singular and historic exemption from the antitrust laws."

Id. (quoting City of San Jose v. Office of the Comm'r of Baseball, 776 F.3d 686, 692 (9th Cir. 2015), cert. denied, 136 S. Ct. 36 (2015)).

187. Senne, 2015 WL 6152476, at *20.

188. City of San Jose, 776 F.3d at 692.

189. See Nathaniel Grow, US Supreme Court Asked To Overturn Baseball's Antitrust Exemption, FANGRAPHS (Apr. 17, 2015), http://www.fangraphs.com/blogs/u-s-supreme-courtasked-to-overturn-baseballs-antitrust-exemption/ [http://perma.cc/2H4B-P2DZ].

190. Sup. Cт. R. 10.

191. Id.

192. Id.

193. See generally Miranda v. Selig, No.14-CV-05349-HSG, 2015 WL 5357854, at*1 (N.D. Cal. Sept. 14, 2015), appeal docketed, No.15-16938 (9th Cir. 2015).

194. Id. at *3. 
laws. ${ }^{195}$ Based on Rule 10 considerations and the inapplicability of the original exemption's rationale, Miranda appears to be a serious threat to baseball's exemption, resulting in major changes to the minor league system. ${ }^{196}$ Therefore, the continued vitality of the exemption is more important now than ever before.

\section{Necessity of the Antitrust Exemption for the Minor Leagues}

Nearly forty million Americans attended a Minor League Baseball game during the 2014 season. ${ }^{197}$ In terms of the games themselves, the minor league games are seemingly the same as the major leagues, the only difference being an increased level of talent and name recognition in MLB. ${ }^{198}$ These differences aside, the minor leagues provide something the major leagues cannot.

In effect, the Major League Rules and Major League Constitution tell their constituent clubs where they will be located. ${ }^{199}$ Antitrust law would necessarily render this sort of agreement illegal. ${ }^{200}$ As a result, the market would be competitive and teams would be free to impede upon the operating territory of other teams. ${ }^{201}$ Clubs would relocate to cities where they could maximize their revenue through ticket sales and, unsurprisingly, this revenue maximization would not happen in places like Rome, Georgia. Rather, large metropolitan areas would provide teams with the greatest economic success. ${ }^{202}$

\section{A. It's More Than a Game: National Collegiate Athletic Ass'n v. Board of Regents of the University of Oklahoma}

The National Collegiate Athletic Association ("NCAA") was created in 1905 and has "adopted and promulgated playing rules, standards of amateurism, standards for academic eligibility, regulations concerning recruitment of athletes, and rules governing the size of athletic squads and coaching staffs." ${ }^{203}$ The first

195. See generally Senne v. Kansas City Royals Baseball Corp., No.14-CV-00608-JCS, 2015 WL 6152476, at*1 (N.D. Cal. Oct. 20, 2015); Miranda, 2015 WL 5357854, at*1; Grow, supra note 189. The Supreme Court might consider the issue compelling because two cases are asking for the exception to be reexamined and because the issue is controversial.

196. See Grow, supra note 189; Grow, supra note 180.

197. Schoenfeld, supra note 5.

198. Id.

199. See generally OfFice of the COMM'R of BASEBALl, supra note 44; see also MAJOR League Baseball Clubs, supra note 27, at 8 (art. V, § 2(b)(3)).

200. See discussion infra Part IV.C and IV.D.

201. See Alex Belth, Ending Baseball's Antitrust Exemption, Baseball Prospectus (Nov. 25, 2001), http://www.baseballprospectus.com/article.php?articleid=1286 [http://perma.cc/ZR4KAQEN].

202. See Kavitha Davidson, Antitrust Exemption Holds Baseball Back a Century, BLOOMBERG VIEw (Apr. 8, 2014, 10:41 AM), http://www.bloombergview.com/articles/2014-04-08/antitrustexemption-holds-baseball-back-a-century [http://perma.cc/6X5Z-WPR3]. Smaller cities will have less appeal to teams who have been trying to move to bigger cities to maximize profit.

203. Nat'l Collegiate Athletic Ass'n v. Bd. of Regents of the Univ. of Okla., 468 U.S. 85, 88 
college football game was televised in 1938 by the University of Pennsylvania. ${ }^{204}$ This game laid the foundation for a television plan that was implemented by the NCAA for the 1951 college football season. ${ }^{205}$ The television plan provided:

$[\mathrm{O}]$ nly one game a week could be telecast in each area, with a total blackout on 3 of the 10 Saturdays during the season. A team could appear on television only twice during a season. The plan also provided that the [National Opinion Research Center] would conduct a systematic study of the effects of the program on attendance. ${ }^{206}$

In 1981, the NCAA adopted a new television plan that was intended to reduce the negative effects of live broadcasts on college football game attendance. ${ }^{207}$ The plan required that eighty-two different college football teams appear on television during a two-year period. ${ }^{208}$ Furthermore, no school could appear on television "more than a total of six times and more than four times nationally, with the appearances to be divided equally between the two carrying networks." ${ }^{209}$ In essence, the television plan limited the total number of televised college football games and the number of televised games in which any one institution could appear. ${ }^{210}$

After institutions began negotiating television contracts with an unaffiliated television company, the NCAA announced it would take disciplinary action against any institution that disobeyed the NCAA's television plan. ${ }^{211}$ As a result of the threat of disciplinary action, the University of Oklahoma filed suit against the NCAA, claiming a violation of antitrust law. ${ }^{212}$ A majority of the Supreme Court recognized the importance of the NCAA in preserving college sports, ${ }^{213}$ but ruled the television restriction placed on college football games violated the Sherman Act. ${ }^{214}$ The Court reasoned:

By participating in an association which prevents member institutions

(1984)

204. Id. at 89 .

205. Id.

206. Id. at 90 .

207. Id. at 91 .

208. Id. at 94 .

209. Id.

210. Id.

211. Id. at 95 .

212. $I d$.

213. The Court noted:

The identification of this "product" [college football] with an academic tradition differentiates college football from and makes it more popular than professional sports to which it might otherwise be comparable ... [T] he integrity of the "product" cannot be preserved except by mutual agreement . . Respondents concede that the great majority of the NCAA's regulations enhance competition among member institutions. Id. at 101-03.

214. Id. at 120 . 
from competing against each other on the basis of price or kind of television rights that can be offered to broadcasters, the NCAA member institutions have created a horizontal restraint . . . [T] he horizontal agreement places an artificial limit on the quantity of televised football that is available to broadcasters and consumers. By restraining the quantity of television rights available for sale, the challenged practices create a limitation on output. ${ }^{215}$

Furthermore, "by curtailing output and blunting the ability of member institutions to respond to consumer preference, the NCAA ha[d] restricted rather than enhanced the place of intercollegiate athletics in the Nation's life."216

Justice White's dissent, which was joined by Justice Rehnquist, was informed by Justice White's unique perspective. ${ }^{217}$ Justice White had first-hand experience with college football. ${ }^{218} \mathrm{He}$ was a star football player for the University of Colorado and was inducted into the College Football Hall of Fame. ${ }^{219}$ In fact, football played such a significant role in his life that, after graduating from Colorado, he postponed his acceptance of the Rhodes Scholarship to study at Oxford in favor of professional football. ${ }^{220}$ Justice White signed a professional contract with the Pittsburgh Pirates (now the Steelers), where he led the NFL in rushing and received what was then the highest-ever salary. ${ }^{221}$ Justice White commingled his football career with his law studies, playing football for the Detroit Lions while attending Yale. ${ }^{222}$

Justice White appropriately disagreed with the majority's position that the restriction of television rights violated the Sherman Act. ${ }^{223}$ At the outset of his dissent, Justice White stated, "[T] he Court errs in treating intercollegiate athletics under the NCAA's control as a purely commercial venture in which colleges and universities participate solely, or even primarily, in the pursuit of profits." ${ }^{224}$ The fundamental policy of the television plan was to "maintain intercollegiate athletics as an integral part of the educational program and the athlete as an integral part of the student body." 225 Justice White went on to explain the NCAA

215. Id. at 99 .

216. Id. at 120 .

217. Id. at $120-36$.

218. Linda Greenhouse, Byron R. White, Longtime Justice and a Football Legend, Dies at 84, N.Y. Times (Apr. 16, 2002), http://www.nytimes.com/2002/04/16/us/byron-r-white-longtimejustice-and-a-football-legend-dies-at-84.html?pagewanted=all [http://perma.cc/6PR7-ESPP].

219. Id.

220. Dennis Hutchinson, White, Byron R., Am. NAT'L Biography Online (July 9, 2008), http://www.anb.org/articles/11/11-62626.html [http://perma.cc/25A6-3LPM].

221. Greenhouse, supra note 218.

222. Byron R. White, OYEZ, http://www.oyez.org/justices/byron_r_white [http://perma.cc/ R5FT-Y7MD] (last visited Jan. 16, 2016).

223. Nat'l Collegiate Athletic Ass'n v. Bd. of Regents of the Univ. of Oklahoma, 468 U.S. 85, 121 (1984).

224. $I d$.

225. Id. at 122 . 
"exist[s] primarily to enhance the contribution made by amateur athletic competition to the process of higher education" 226 and, in reaching this goal, "the organization and its members seek to provide a public good - a viable system of amateur athletics - that most likely could not be provided in a perfectly competitive market." 227 Finally, Justice White declared:

The legitimate noneconomic goals of colleges and universities should not be ignored in analyzing restraints imposed by associations of such institutions on their members, and these noneconomic goals "may require that a particular practice, which could properly be viewed as a violation of the Sherman Act in another context, be treated differently." 228

In summary, Justice White advocated for the exclusion of college football from the reach of antitrust law because it provided something more than the game itself.

B. Approving Output Restrictions: Broadcast Music, Inc. v. Columbia Broadcasting Systems, Inc. ${ }^{229}$

In Broadcast Music, Inc. v. Columbia Broadcasting Systems, Inc., the Supreme Court was tasked with determining whether "the issuance by ASCAP [American Society of Composers, Authors and Publishers] and BMI [Broadcast Music, Inc.] to CBS [Columbia Broadcasting Systems, Inc.] of blanket licenses to copyrighted musical compositions at fees negotiated by them is price fixing per se unlawful under the antitrust laws." 230

In 1914, Victor Herbert and other composers created ASCAP out of necessity: it was no longer feasible for individual copyright owners to negotiate with and license the users because of the large number of composers who performed copyrighted music for profit. ${ }^{231} \mathrm{BMI}$ operated in a similar manner as ASCAP, and BMI and ASCAP collectively controlled nearly every domestic copyrighted composition. ${ }^{232}$ Both ASCAP and BMI operated "primarily through blanket licenses, which [gave] the licensees the right to perform any and all of the compositions owned by the members or affiliates as often as the licensees desire[d] for a stated term." ${ }^{233}$ CBS alleged that ASCAP and BMI violated the antitrust laws because, inter alia ${ }^{234}$ the companies were unlawful monopolies and

226. Id. (quoting Ass'n for Intercollegiate Athletics for Women v. Nat'l Collegiate Athletic Ass'n, 558 F. Supp. 487, 494 (D.C. Cir. 1983)).

227. Id. (emphasis added) (citing Hennessey v. Nat'1 Collegiate Athletic Ass'n, 564 F.2d 1136, 1153 (5th Cir. 1977)).

228. Id. at 104 (quoting Goldfarb v. Va. State Bar, 421 U.S. 773, 788 (1975)).

229. Interestingly enough, Justice White wrote the majority opinion for this case.

230. Broad. Music, Inc. v. Columbia Broad. Sys., Inc., 441 U.S. 1, 4 (1979).

231. Id. at 5 .

232. Id.

233. $I d$.

234. CBS's other claims included a concerted refusal to deal and misuse of copyrights. Id. at 6 . 
the blanket licensing was illegal price fixing. ${ }^{235}$

The district court ruled the blanket licensing practice was not per se illegal and ASCAP and BMI were not monopolists under Section 1 of the Sherman Act because "direct negotiation with individual copyright owners [was] available and feasible [so] there [was] no undue restraint of trade . . . or monopolization."236 However, the Second Circuit held the blanket licenses were per se illegal under the Sherman Act as a form of price fixing. ${ }^{237}$ Because of the "importance of the issues to the antitrust . . laws," the Supreme Court granted certiorari. ${ }^{238}$

At the outset, the Supreme Court noted that "[b]oth organizations [ASCAP and BMI] plainly involve concerted action in a large and active line of commerce," but that this concerted action "may have redeeming competitive virtues and that the search for those values is not almost sure to be in vain." ${ }^{239} \mathrm{In}$ determining whether the practices were per se illegal, the Court had to decide whether "the practice facially appears to be one that would always or almost always tend to restrict competition and decrease output . . . or instead one designed to 'increase economic efficiency and render markets more, rather than less, competitive." ${ }^{240}$ Justice White found that "the blanket license . . is not a "naked restraint of trade with no purpose except stifling of competition,", but, rather, ASCAP and BMI "reduce costs absolutely by creating a blanket license that is sold only a few, instead of thousands, of times ... [and] a bulk license of some type is a necessary consequence of the integration necessary to achieve these efficiencies." ${ }^{241}$ Because of the "redeeming competitive virtues," the Court ultimately held the blank license was not a per se violation of antitrust law and remanded the case for analysis under the Rule of Reason. ${ }^{242}$ Broadcast Music Inc., requires that, where economic efficiency cannot be achieved without an agreement among competitors, the agreement must be analyzed under the Rule of Reason.

\section{Broadcast Music, Inc., National Collegiate Athletic Ass'n, and Minor League Baseball}

Congress passed the Curt Flood Act of 1998 in hopes of resolving repeated challenges brought as a result of MLB's antitrust exemption. ${ }^{243}$ The Act provides, "[T]he conduct, acts, practices or agreements of persons in the business of organized professional major league baseball directly relating to or affecting employment of major league baseball players to play baseball at the major

\footnotetext{
235. Id.

236. $I d$.

237. Id.

238. Id. at 7 .

239. Id. at 10,13 .

240. Id. at 19-20 (citations omitted).

241. Id. at 20-21 (citations omitted).

242. Id. at 24-25.

243. 15 U.S.C. $\S 26 b$ (2012).
} 
league level are subject to the antitrust laws." 244 In regards to Minor League Baseball, the Act states: "[This section does not apply to] any conduct, acts, practices, or agreements of persons engaging in, conducting or participating in the business of organized professional baseball relating to or affecting employment to play baseball at the minor league level. ${ }^{245}$ Therefore, the minor leagues are exempt from antitrust liability.

With the goal of antitrust being the maximization of consumer welfare, ${ }^{246}$ it not only makes sense that Minor League Baseball enjoys an exemption, it is imperative that it does. Examining the Supreme Court's decisions in Broadcast Music, Inc. v. Columbia Broadcasting Systems, Inc. and National Collegiate Athletic Ass'n v. Board of Regents of the University of Oklahoma makes it clear that the antitrust exemption is necessary for Minor League Baseball. Broadcast Music, Inc. allowed output restrictions because the restrictions actually enhanced output by creating a completely new product and were necessary for the market to function properly. ${ }^{247}$ Similarly, professional baseball restricts clubs from relocating freely, but this restriction enhances output and consumer welfare by providing live, professional baseball games to individuals in smaller cities that would otherwise not have access to games. These Minor League Baseball games provide a wholly different product from that offered by MLB. Furthermore, Justice White's dissent in National Collegiate Athletic Ass' $n$ speaks directly to Minor League Baseball's core attributes. ${ }^{248}$ The minor leagues provide communities with a certain amount of intrinsic value; something that cannot be measured through dollars and cents. Clubs provide a "public good ... that most likely could not be provided in a perfectly competitive market." 249 Minor league teams offer citizens of small towns with a common identity; they can rally around their hometown team and connect with others in the community. The "noneconomic goals" 250 of Minor League Baseball should not be ignored, even if that means making leagues exempt from antitrust scrutiny.

However, a court likely would not analyze professional baseball's franchise location restrictions based on Broadcast Music, Inc. or Justice White's dissent. Instead, a court would take the majority approach in National Collegiate Athletic $A s{ }^{\prime} n$ - a purely economic endeavor. ${ }^{251}$ From a purely economic perspective, the

244. Id. $\S 26 \mathrm{~b}(\mathrm{a})$ (emphasis added).

245. Id. $\S 26 \mathrm{~b}(\mathrm{~b})(1)$.

246. See supra Part II.A.2 (discussing the modern-day goals of antitrust law).

247. See Broad. Music, Inc. v. Columbia Broad. Sys., Inc., 441 U.S. 1, 21 (1979) (“[A] bulk license of some type is a necessary consequence of the integration necessary to achieve these efficiencies.").

248. See Nat'l Collegiate Athletic Ass'n v. Bd. of Regents of the Univ. of Okla., 468 U.S. 85, 121 (1984) (quoting John Weistart \& CYM Lowell, The LaW of SpORTS $§ 5.12$ (1979)) (“[I]t is clear that other, non-commercial goals play a central role in [colleges'] sports programs.").

249. Id. at 97 (citing Hennessey v. Nat'l Collegiate Athletic Ass'n, 564 F.2d 1136, 1153 (5th Cir. 1977)).

250. Id. at 104 .

251. See id. at 120 (“[R]ules that restrict output are hardly consistent with [the NCAA's role] 
location requirements probably violate antitrust laws because they restrict competition between cities to vie for professional baseball clubs. ${ }^{252}$ Evidence of this likely result can be found from the Ninth Circuit's decision in Los Angeles Memorial Coliseum Commission v. National Football League. ${ }^{253}$ In that case, the Oakland Raiders wanted to move from Oakland to Los Angeles, but the NFL would not allow the move to happen. ${ }^{254}$ The court ruled the NFL's restraint on the relocation of the Raiders was unreasonable and violated the antitrust laws. ${ }^{255}$ If professional baseball did not have its antitrust exemption and a court ruled similar to the Ninth Circuit in Raiders, teams would be able to move freely, causing smaller markets to lose their minor league clubs and decreasing consumer welfare in those cities.

\section{Minor League Baseball's Economic Justification for the Exemption}

Aside from compromising professional baseball's important franchise location structure if the antitrust exemption did not exist, the pay structure within Minor League Baseball likely would change without the exemption. Based on basic economic principles, a sweeping change in the landscape of Minor League Baseball could potentially accompany this change in pay structure. The antitrust exemption has been characterized as "allow[ing professional baseball] to openly collude on the working conditions for the development of its chief commodity: young baseball players. ${ }^{256}$ Under this directive, the typical minor league salary ranges from $\$ 1100$ per month for players in short-season leagues to $\$ 2150$ per month for players in Triple-A. ${ }^{257}$

Basic economic principles of supply and demand guide the argument for the necessity of the antitrust exemption for the continued viability of Minor League Baseball in terms of player wages. Simply put, demand is "the rate at which consumers want to buy a product." 258 One factor determining demand is a consumers ability to buy, meaning "to buy a good at specific price, an individual

... [B]y curtailing output and blunting the ability of member institutions to respond to consumer preference, the NCAA has restricted rather than enhanced the place of intercollegiate athletics.").

252. See 15 U.S.C. $§ 1$ (1982) ("Every contract, combination . . or conspiracy, in restraint of trade or commerce . . . is declared to be illegal.").

253. See generally L.A. Mem'l Coliseum Comm'n v. Nat'1 Football League, 726 F.2d 1381 (9th Cir. 1984).

254. Id. at 1385 .

255. Id. at 1401 .

256. Second Consolidated Amended Complaint for Violations of Federal and State Wage and Hour Laws at 1, Senne v. Office of the Comm'r of Baseball, No. 3:14-cv-00608-JCS, 2015 WL 6152476 (N.D. Cal. Oct. 20, 2015).

257. Leventhal, supra note 63.

258. Joseph Whelan \& Kamil Msefer, Mass. Inst. of Tech. Sys. Dynamics in Educ. Project, ECONOMic SupPly AND Demand 6 (Jan. 14, 1996), available at http://ocw.mit.edu/ courses/sloan-school-of-management/15-988-system-dynamics-self-study-fall-1998-spring1999/readings/economics.pdf [perma.cc/UQ4S-YZSA]. 
must possess sufficient wealth or income." ${ }^{259}$ When the price for a product is high, quantity demanded is low; when the price is low, quantity demanded is high. ${ }^{260}$

If the antitrust exemption no longer existed, minor league clubs likely would not be required to pay players a predetermined amount according to the Major League Rules. As a result, the market for Minor League Baseball players would be competitive, allowing certain clubs to pay higher prices for more talented players. Therefore, in this case, economic theory would predict that as price-here, the wages of minor league players - increases, the demand for minor league players decreases, ceteris paribus. ${ }^{261}$ A naïve assessment of professional baseball's structure would suggest the inverse would hold true for supply: as price increases, the quantity supplied-minor league players-would increase. However, this is misguided and fails to tell the entire story. Because teams would be able to spend more for the top amateur baseball talent, they would have less money to spend on the other players selected in the lower rounds of the draft. As a result, fewer high school and college baseball players would be signed to minor league contracts, decreasing the total number of players in the minor league system. This decreased number of players would prevent minor league clubs from filling rosters-in particular, the lower-class teams (e.g., Low-A, A-Short Season, and Rookie). Clearly, without enough players to fill the roster spots in these leagues, the clubs would cease to exist. ${ }^{262}$ Therefore, the cities where these teams are located would no longer have the ability to enjoy the fruits of baseball's antitrust exemption, namely Minor League Baseball. As argued above, consumer welfare - the goal of antitrust law-in these cities would diminish. Simple economics instructs this result and exemplifies the need for the antitrust exemption.

\section{CONCLUSION}

Professional baseball's important structure is maintained through the existence of the antitrust exemption and is vital for the survival of the minor leagues. Minor League Baseball improves consumer welfare, thus achieving the goal of antitrust law. ${ }^{263}$ Millions of children around the world grow up with dreams of one day playing professional baseball. Although only a small percentage of children ever make this dream a reality, without the antitrust

259. Id.

260. Id.

261. "[I]f all other relevant things, factors, or elements remain unaltered." Ceteris Paribus, Merriam-Webster, http://www.merriam-webster.com/dictionary/ceteris\%20paribus [http://perma.cc/P3P6-MGZH] (last visited Jan. 22, 2015).

262. See Baseball's Antitrust Immunity: Hearing Before the Subcomm. on Antitrust, Monopolies, and Business Rights of the Senate Comm. on the Judiciary, 102d Cong. (1992) (statement of Gary Roberts predicting that all Class-A minor league teams could potentially be eliminated if the antitrust exemption were repealed).

263. See Roberts, supra note 90 (arguing the goal of antitrust law is to maximize consumer welfare). 
exemption, even fewer would be able to do so. "We're all told at some point in time that we can no longer play the children's game, we just don't ... know when that's gonna [sic] be. Some of us are told at eighteen, some of us are told at forty, but we're all told. ${ }^{" 264}$ Ridding baseball of its antitrust exemption would require more people being told at eighteen that they can no longer play the game. This alone decreases consumer welfare for those individuals.

Recently, MLB's new commissioner, Rob Manfred, recognized the importance of access to live professional baseball games:

We need to make sure we capture the next generation of fans in a way that baseball has always captured fans. To me, that's about parents and grandparents taking kids to the park at an early age so they learn to appreciate the game and the bonding experience that takes place ... [Going to games] was the beginning of my passion for the game. I think that dynamic has always been fundamental to the game's popularity and success. ${ }^{265}$

Without the exemption, Commissioner Manfred's very ideal would not be possible. Small towns across the country could lose their beloved minor league club, leaving the citizens of those towns with little on which they can lean.

"The fundamental reason for the popularity of [baseball] is the fact that it is a national safety valve ... It serves the same purpose as a revolution in Central America or a thunderstorm on a hot day ... Baseball is second only to Death as a leveler. ${ }^{266}$ The importance of baseball in America cannot be overstated, and the antitrust exemption ensures that folks for years to come will be able to enjoy America's Pastime.

264. Moneyball (Columbia Pictures 2011).

265. Jerry Crasnick, Rob Manfred's Top Five Priorities, ESPN (Jan. 25, 2015), http://espn.go. com/mlb/story/_id/12218054/new-mlb-commissioner-rob-manfred-top-five-priorities [http://perma.cc/66TY-FCWA].

266. Allen Sangree, "Fans" and Their Frenzies: The Wholesome Madness of Baseball, 17 EVERYBODY's MAG. 378 (1907). 